\title{
VIE-toimijoiden kirjo Aleksanteri-foorumissa 9.5.2019
}

Ensimmäistä kertaa järjestetty valtakunnallinen Aleksanteri-foorumi kokosi toukokuussa saman katon alle yli 180 aktiivista Venäjän ja ItäEuroopan alueiden parissa toimijaa. Helsingin yliopistolla järjestetyssä tapahtumassa oli edustettuna yli 80 tahoa koulutuksen, tutkimuksen, liike-elämän ja kansalaisyhteiskunnan aloilta. Tapahtuman ideana oli paitsi tuoda yhteen alan toimijoita, myös kartoittaa tämänhetkistä VIEosaamisen tilaa Suomessa.

Foorumi rakentui kaikille yhteisestä aamuohjelmasta ja iltapäivän neljästätoista työryhmäkeskustelusta. Avauspuheenvuorot esittivät Markku Kangaspuro (Aleksanteri-instituutti) ja Ilkka Herlin (Cargotec ja Aleksanteri-instituutin neuvottelukunta). Kangaspuro puhui suomalaisen VIE-osaamisen pitkistä perinteistä sekä tutkitun tiedon yhteiskunnallisista merkityksistä. Herlin toi esille kokemuksiaan Venäjä-yhteistyöstä ja korosti tarvetta kansainvälisten yhteistyömuotojen tiivistämiseen globaalien haasteiden edessä.

Aamupäivä jatkui asiantuntijapaneelilla, jossa pohdittiin VIE-toimijoiden ajankohtaisia tarpeita ja haasteita sekä VIE-osaamisen merkitystä suomalaiselle yhteiskunnalle. Omia näkökulmiaan paneelissa olivat jakamassa Pekko Kohonen (Cultura-säätiö), Minna Likan- der (ainejärjestö Sasha ry), Katalin Miklóssy (Aleksanteri-instituutti), Ilkka Salonen (East Office of Finnish Industries), Joni Virkkunen (VIETS ry ja Itä-Suomen yliopisto) ja Hanna Smith (Hybrid CoE). Esille nousi yhtäältä huoli kielitaitoisten osaajien vähäisestä määrästä ja toisaalta alan opiskelijoiden epävarmuus oman osaamisen relevanssista ja riittävistä työelämätaidoista. Puhuttiin myös verkostojen ja viestinnän tärkeydestä alalla, jossa aktiivisia toimijoita ja asiantuntemusta löytyy viljalti eri yhteiskunnan ja työelämän osa-alueilta.

Panelistit keskustelivat myös eri VIE-alueen maiden eroista ja erityispiirteistä, jotka asettavat haasteita alueen ilmiöiden seuraamiselle. Toimintaympäristön tunteminen on tärkeä osa aluetuntijan osaamista, mutta viime aikoina esimerkiksi eräät Itä-Euroopan maat ovat muuttuneet toimintaympäristöltään niin vauhdilla, että tilanteen seuraaminen on paikoitellen vaikeaa alueeseen vihkiytyneillekin. Aamupäivän ohjelman lopuksi Kansalliskirjaston Slaavilaisen kirjaston palvelupäällikkö Irma Reijonen esitteli osallistujille kirjaston historiaa ja kertoi aineistokokoelman taustasta ja erityispiirteistä.

Aleksanteri-foorumin iltapäivä koostui neljästätoista eri temaattisesta työryhmästä. Työryh-

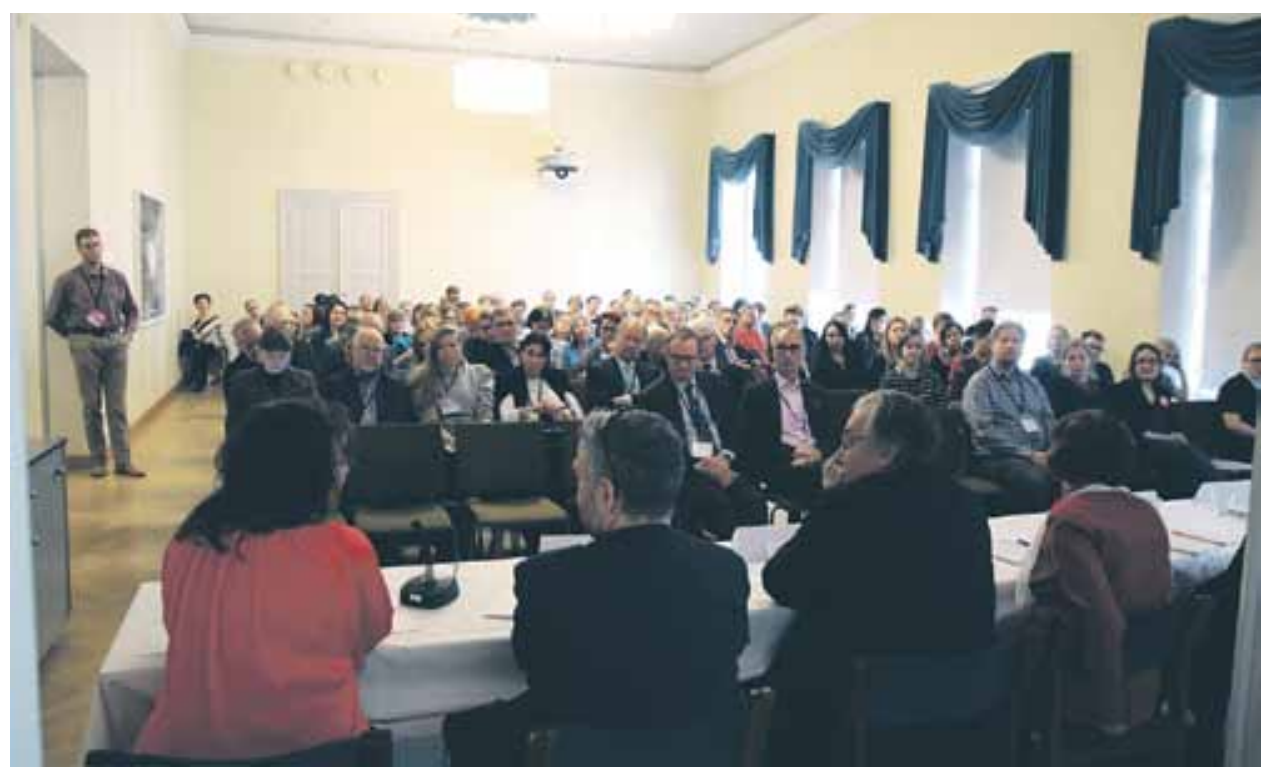

Aamupäivän paneelikeskustelussa pohdittiin Venäjään ja itäiseen Eurooppaan liittyvän osaamisen merkitystä suomalaiselle yhteiskunnalle. 
mät muodostettiin avoimeen kutsuun vastanneista, ja kukin ryhmä määritteli itsenäisesti oman ryhmänsä kokoonpanon ja aiheen. Työryhmien aihepiirejä olivat esimerkiksi koulutus, työelämä, Venäjän talous ja Venäjän ulkopolitiikka. Myös kielten opetus, aluekehitys ja kansalaisjärjestöt saivat omat ryhmänsä.

Vaikka kukin ryhmä keskittyi omien erityiskysymystensä pureskeluun, nousi iltapäivän sessioista esiin eri ryhmiä yhdistäviä aiheita. Tapahtuman nimessäkin esiintyvä valtakunnallisuus oli luonnollisesti yksi paljon puhuttaneista teemoista. Usein ilmavaksi jäävä käsite sai päivän mittaan konkreettista tarttumapintaa, kun ryhmät pohtivat valtakunnallisuuden merkitystä ja ilmenemistä oman työnsä ja alansa näkökulmista. Foorumin puheenvuorojen perusteella valtakunnallinen yhteistyö koettiin kentälläkin ensiarvoisen tärkeäksi, joskin monin paikoin myös käytännössä haasteelliseksi.

Toinen puhututtanut aihe oli hiipunut kiinnostus VIE-maita ja erityisesti Venäjää kohtaan. Monet kertoivat havainneensa ilmiön viime aikoina esimerkiksi opiskelijamäärien laskuna. Tämä trendi yhdistettynä eläköitymisiin ja henkilövaihdoksiin on aiheuttanut huolta yhteistyön, kontaktien ja osaamisen jatkuvuudesta tulevaisuudessa esimerkiksi aluekehityksen ja taloussuhteiden osalta. Ratkaisuksi foorumilla tarjottiin esimerkiksi valtakunnallisia verkkokursseja ja jatkuvan oppimisen muotoja sekä maisteriopiskelijoiden houkuttelemista alueen tutkimuksen pariin tutkimusavustamisen ja gradupankin avulla. Ideoitiin myös tapoja, joilla aluetta voisi lähestyä uusista näkökulmista. Näitä olivat esimerkiksi kulttuurin ja matkailun näkökulmat ja suomalaisille vieraampien alueiden, kuten trendikkään Keski-Aasian tutuksi tekeminen.

Tutkimuksen ja koulutuksen osalta keskusteltiin rahoituksen ja toimintaympäristöjen muutoksesta. Monista foorumin puheenvuoroista välittyi, että tämänhetkinen tilanne luo yhteistyön sijaan kilpailullisia rakenteita, jotka hankaloittavat VIE-tietotaidon parasta mahdollista käyttöä. Aleksanteri-foorumin saaman palautteen ja foorumipäivän keskusteluiden perusteella vaikuttaakin siltä, että vastaavan kaltaisille, valtakunnallista ja monialaista viestintää, yhteistyötä sekä verkostoja rakentaville tapahtumille on kysyntää.

Juulia Heikkinen maailmanpolitiikan tutkimuksen maisteriopiskelija

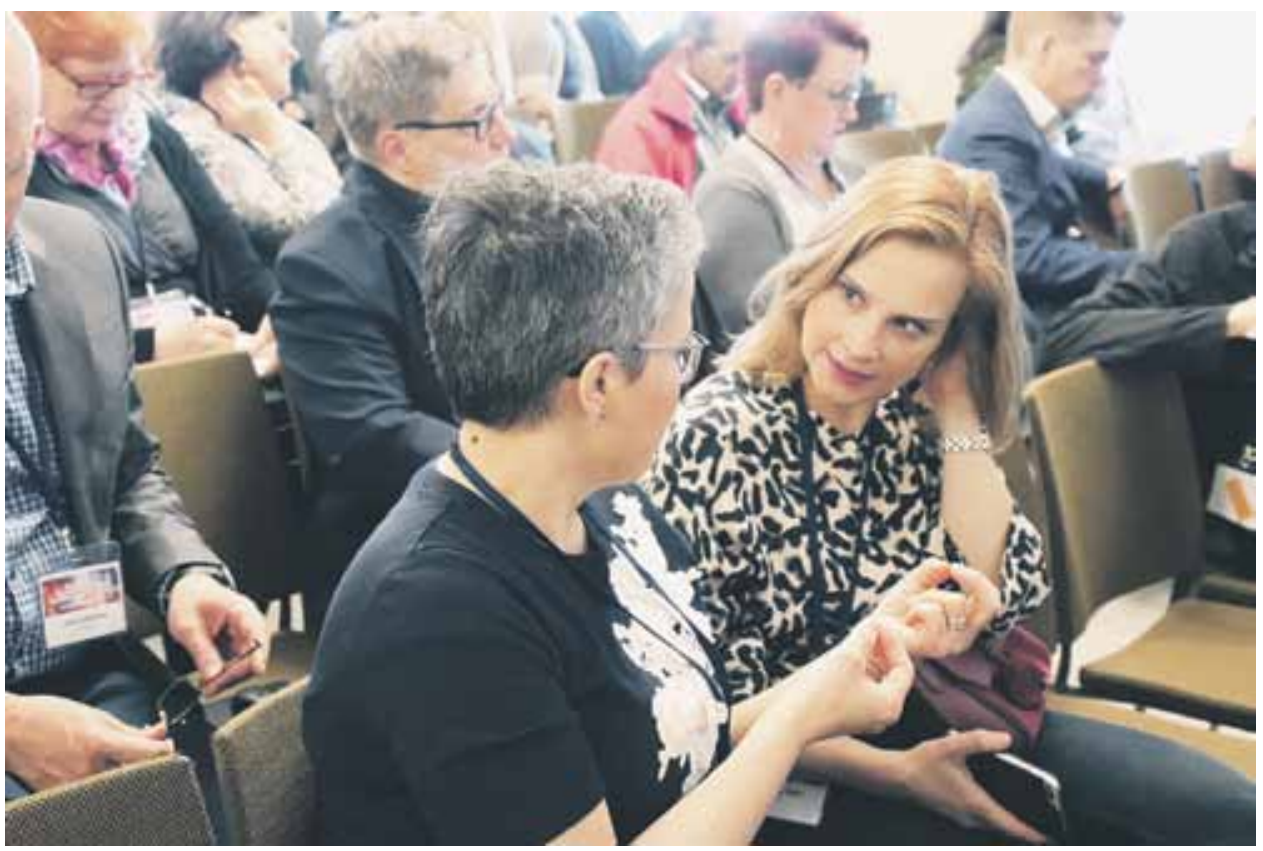

Aleksanteri-foorumi tarjosi mahdollisuuden ajatusten vaihtoon ja monialaiseen verkostoitumiseen Suomen VIE-osaajien kesken. 